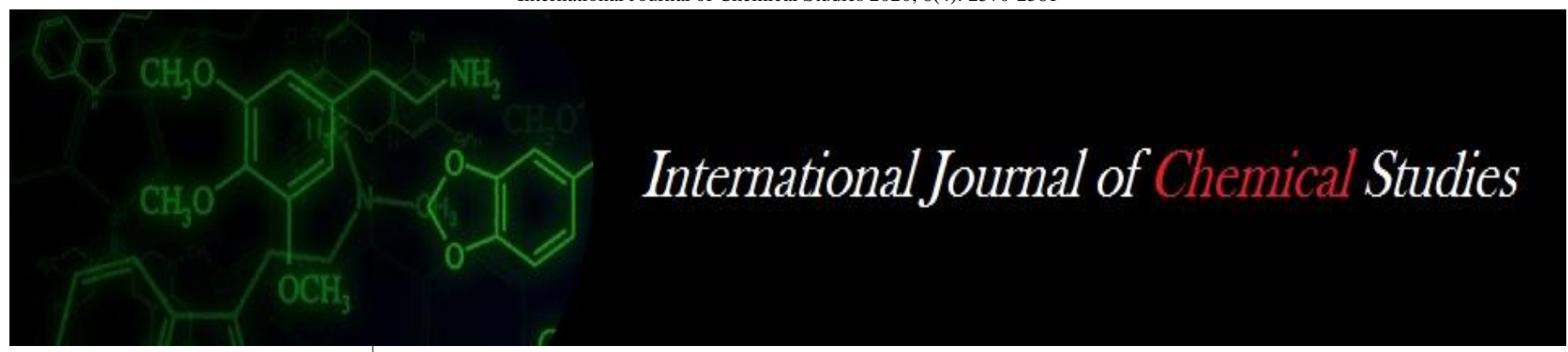

P-ISSN: 2349-8528

E-ISSN: 2321-4902

www.chemijournal.com

IJCS 2020; 8(4): 2570-2581

(C) 2020 IJCS

Received: 21-05-2020

Accepted: 24-06-2020

\section{Charul Verma}

Department of Plant Pathology,

Dr. YS Parmar University of

Horticulture and Forestry,

Nauni, Solan, Himachal

Pradesh, India

\section{Savita Jandaik}

Department of Plant Pathology,

Dr. YS Parmar University of

Horticulture and Forestry,

Nauni, Solan, Himachal

Pradesh, India

\section{Bhupesh K Gupta}

Department of Plant Pathology,

Dr. YS Parmar University of

Horticulture and Forestry,

Nauni, Solan, Himachal

Pradesh, India

\section{Natasha Kashyap}

Department of Plant Pathology,

Dr. YS Parmar University of

Horticulture and Forestry,

Nauni, Solan, Himachal

Pradesh, India

Suryaprakash VS

Department of Plant Pathology,

Dr. YS Parmar University of

Horticulture and Forestry,

Nauni, Solan, Himachal

Pradesh, India

Sushil Kashyap

Krishi Vigyan Kendra, Bastar,

Chhattisgarh, India

\section{Anurag Kerketta}

College of Horticulture and

Research Station, Jagdalpur,

Bastar, Chhattisgarh, India

Corresponding Author:

\section{Charul Verma}

Department of Plant Pathology,

Dr. YS Parmar University of

Horticulture and Forestry,

Nauni, Solan, Himachal

Pradesh, India

\section{Microbial metabolites in plant disease management: Review on biological approach}

\author{
Charul Verma, Savita Jandaik, Bhupesh K Gupta, Natasha Kashyap, \\ Suryaprakash VS, Sushil Kashyap and Anurag Kerketta
}

DOI: https://doi.org/10.22271/chemi.2020.v8.i4ad.10026

\begin{abstract}
Biological control of plant diseases through microbial metabolites is an eco-friendly and effective means of reducing or mitigating crop losses. Among these microbial metabolites, antibiotics produced by different bacteria and fungi are now proving to be a new source of potential biopesticides. Various actinomycetes like Streptomyces, Actinoplanes, Actinomadura, Micromonospora, Streptosporangium, Streptoverticillium and Spirillospora, bacteria belonging to the genera Agrobacterium, Bacillus, Burkholderia, Enterobacter, Erwinia, Lysobacter, Pseudomonas, Serratia and a few fungal genera such as Ampelomyces, Aspergillus, Coniothyrium, Gliocladium, Laetisaria, Penicillium, Phlebiopsis, Sporodesmia, Talaromyces, Tilletiopsis, Trichoderma, Trichothecium and non-pathogenic Fusarium are prolific producers of secondary metabolites which at low concentrations are lethal to the growth or metabolic activities of other microorganisms. Phenazine-1-carboxylic acid, pyocyanin, 2,4diacetylphloroglucinol, pyoluteorin, pyrrolnitrin, hydrogen cyanide, siderophores, zwittermicin a 14, kurstakin, azole compound, ammonia, wuyiencin, viridin, trichodermin, 6-pentyl-2h-pyran-2-one, gliovirin, gliotoxin, harzianopyridone, harzianolide, massoilactone and d-decanolactone, viridepyronone, koningins, t22 azaphilone, t39 butenolide, volatile compounds and trichothecin are some of the metabolites which have been used in plant disease control. These microbial metabolites can be used as a substitute for chemical fungicides and paved way for its use in sustainable agriculture as biopesticides.
\end{abstract}

Keywords: Secondary metabolites, plant disease, microbes, biopesticides and management

\section{Introduction}

Agriculture, the backbone of Indian economy, contributes to overall economic growth of the country and determines standard of living for more than 50 per cent of Indian population and contributes 14.4 per cent in GDP. Modern agriculture is evolving through agricultural innovations and farming practices and helping farmers to increase efficiency and reduce requirement of natural resources like water, land and energy necessary to meet world's food, fuel and fibre needs. In order to get higher yields, farmers practice monocropping and inadvertently make non-judicious use of chemical fertilizers resulting in pests and diseases outbreaks. Agrochemicals are invariably used to manage these diseases and posing threat to human health as well as causing widespread environmental damage. Non-judicious use of agrochemicals leads to development of fungicide resistance in pathogens. These environmental and consumer concerns have led the researchers to focus interest on of biological control agents development as an environment friendly and sustainable strategy for the protection of agricultural and horticultural crops against phytopathogens (Dunne et al., 1998) ${ }^{[30]}$, as an alternative to the chemical fungicides (Ravikumar, 1998; Biju, 2000) ${ }^{[122,18]}$, thus gaining importance in modern agriculture.

Biological control is an eco-friendly and effective means of reducing or mitigating plant diseases through the use of natural enemies i.e., microorganisms. These microbe-based agroagents are used as either whole organism or their metabolites. Interestingly, some of the microbial metabolites that are used in plant disease control programme are of great importance. Micro organisms produce a wide range of secondary metabolites like antibiotics, hormones, enzymes, pigments, mycotoxins etc. The discovery of penicillin, the first broadspectrum antibiotic led researchers for the exploitation of microorganisms for secondary metabolite production, which revolutionized the field of microbiology (Keller et al., 2006). 
Microbial secondary metabolites are low molecular bioactive compounds synthesized during a subsequent production stage (idiophase) of microbial growth. The secondary metabolite production is controlled by special regulatory mechanisms in microorganisms, as their production is generally repressed in logarithmic phase and depressed in stationary growth phases. It is commonly observed during microbial interaction of antagonistic microorganisms and pathogens.

Among these microbial metabolites, antibiotics produced by different bacteria, actinomycetes and fungi is now proving to be a new source of potential biopesticides. Antibiotics are low molecular weight compounds produced by microorganisms which at low concentrations are lethal to the growth or metabolic activities of other microorganisms (Handelsman and Stabb, 1996) ${ }^{[100]}$. In many biocontrol systems, one or more antibiotics have been shown to play a role in disease suppression and have been extensively emphasized by many researchers (Handelsman and Stabb, 1996; Yamaguchi, 1996;

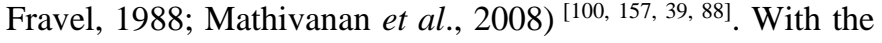
advent of new screening and isolation techniques, a variety of antibiotics have been identified. Hence, in the recent years, the use of secondary metabolites of microbial origin is gaining incentive in crop protection and such metabolites may become a supplement or an alternative to chemical control (Fravel, 1988; Prabavathy et al., 2006; Mathivanan et al., 2008) $[39,117,88]$. Since these secondary metabolites are biologically synthesized, they are highly target oriented and hence, ecofriendly for beneficial organisms. Being biological origin, these metabolites are inherently biodegradable and often do not persist in nature and are safe to the environment (Suzni, 1992; Yamaguchi, 1996; Prabavathy et al., 2008) ${ }^{[138,}$ 157, 117]. The antibiotics produced by biological control agents are unique and advantageous over their competitors i.e., the

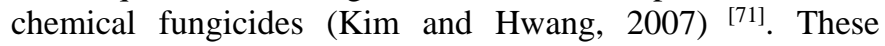
microbial metabolites can be used for the synthesis of plant protective chemicals as lead molecules, thus open up new vistas for entrepreneurs and industrialists (Jayaprakashvel and Mathivanan, 2011). Thus, worldwide interest in these have been renewed and presently several plant diseases are being managed by the use of microbial metabolites.

\section{Source of secondary metabolites}

\section{Actinomycetes}

Actinomycetes are potent producers of a wide variety of secondary metabolites with diverse biological activities, which include therapeutically and agriculturally important compounds (Tanaka and Omura, 1993) ${ }^{[142]}$. Over 1,000 secondary metabolites from actinomycetes have been discovered during 1988-1992. Most of these compounds are produced by various species of the genus Streptomyces. In fact, about 60 per cent of the new insecticides and herbicides reported to be originated from Streptomyces (Tanaka and Omura, 1993) [142]. Actinomycetes have produced various antibacterial, antifungal, nematicidal and herbicidal antibiotic compounds and many are used in agriculture. Several species of actinomycetes belonging to the genera Streptomyces, Actinoplanes, Actinomadura, Micromonospora, Streptosporangium, Streptoverticillium and Spirillospora have been successfully used as potent antagonists against various phytopathogens.

Streptomyces is the dominant genera among actinomycetes known to produce numerous types of antibiotics, of which, many of them, for example, validamycin and kasugamycin have been commercialized as fungicides (Tanaka and Omura, 1993; Mathivanan et al., 2008) [142, 88]. The tetracyclines, chloramphenicol, neomycin, erythromycin, vancomycin, kanamycin, cephalosporin and rifamycin, are few of the antibacterial antibiotics produced by actinomycetes (Prabavathy et al., 2008) ${ }^{[117]}$.

\section{Bacteria}

In the prokaryotic group, bacteria belonging to the genera Agrobacterium, Bacillus, Burkholderia, Enterobacter, Erwinia, Lysobacter, Pseudomonas and Serratia have been successfully used as biological control agents against many plant diseases. Among these unicellular bacteria Bacillus and Pseudomonas is prolific producer of antibiotics.

\section{a. Fluoroscent Pseudomonads}

Among various BCAs, fluorescent pseudomonads (FPs) are found to be the prolific producers of a wide variety of metabolites such as phenazines (Gurusiddaiah et al., 1986; Thomashow and Weller, 1988; Pierson and Thomashow, 1992; Chin-A-Woeng et al., 1998) [43, 145, 114, 21], phenolics (Keel et al., 1990, 1992; Vincent et al., 1991) ${ }^{[67,150]}$, pyrroletype compounds (Homma and Suzui, 1989; Pfender et al., 1993) [52, 112], polyketides (Nowak-Thompson et al., 1994; Kraus and Loper, 1995) ${ }^{[104,76]}$, peptides (Nielsen et al., 1999; Sorensen et al., 2001) [103, 135], phloroglucinols (Dwivedi and Johri 2003) ${ }^{[31]}$, hydrogen cyanide (Castric 1981; Bagnasco et al. 1998; Rodriguez and Fraga 1999; Siddiqui 2006) ${ }^{[131]}$ and siderophores (Hamdan et al. 1991; Meyer et al. 2002).

\section{b. Bacillus sp.}

Antimicrobial metabolites of Bacillus spp. have been used against plant diseases (Kavitha et al., 2005) ${ }^{[66]}$. Bacillus spp. are found to produce many antibiotics such as zwittermycin A (Smith et al., 1993) ${ }^{[134]}$, bacillomycins, fungicin (Koumoutsi et al., 2004) [75], kanosamine, rhizocticin C, iturins (Paulitz and Belanger, 2001; Kloepper et al., 2004) [73, 111] and saltavalin and are also capable of producing thermostable antimicrobial peptides (Emmert and Handelsman, 1999; Kavitha et al., 2005; Leclere et al., 2005; Zhao et al., 2010) $[34,66,78,160]$. Bacteriocins are reported as biopreservatives in food and beverages, and biocontrol agents in agriculture (Bais et al., 2004). Bacteriocins such as thuricin, thuricin 7, thuricin $\mathrm{S}$, thuricin CD 19, thuricin 439A and thuricin 439B, bacthuricin F4, tochicin, kurstakin 18 and entomocin to be the precursors of antibiotics (Sansinenea and Ortiz, 2011) ${ }^{[128]}$.

Other bacteria such as Agrobacterium radiobacter, Burkholderia cepacia, Pantoea agglomerans and Lysobacter sp. have been reported to produce various antibiotic compounds such as agrocin 84 (Kerr, 1980) ${ }^{[68]}$, pyrrolnitrin, pseudane (Homma et al., 1989) ${ }^{[52]}$, herbicolin (Sandra et al., 2001) [127] and xanthobaccin A (Islam et al., 2005) [160] respectively.

\section{Fungi}

A number of fungal genera namely, Ampelomyces, Aspergillus, Coniothyrium, Gliocladium, Laetisaria, Penicillium, Phlebiopsis, Sporodesmia, Talaromyces, Tilletiopsis, Trichoderma, Trichothecium and non-pathogenic Fusarium are known to produce biologically active secondary metabolites that are having potential in controlling plant pathogens (Doumbou et al., 2002; Mathivanan and Manibhushanrao, 2004; El-Tarabily and Sivasithamparam, 2006; Mathivanan et al., 2006; Prabavathy et al., 2008; Ramesh, 2009) [27, 92, 33, 93, 117, 121]. Other fungi like Aphanocladium album, Acremonium obclavatum, Myrothecium verrucaria, Verticillium chlamydosporium, 
Penicillium brevicompactum, Penicillium expansum, Penicillium pinophilum and Coniothyrium minitans were also reported to produce antimicrobial metabolites against plant pathogens. However, their potential have inadequately been exploited in plant protection (Liu and Li, 2004; Mathivanan et al., 2008) ${ }^{[83,88]}$.

Among fungal BCAs, Trichoderma spp. is known to produces a wide range of volatile and non-volatile antibiotic secondary metabolites. Trichoderma species are free-living fungi which are highly interactive in root, soil and foliar environments. Anthraquinones are well-known metabolites of Trichoderma species. In 1967 a wild strain of $T$. viride have been isolated from soil and has been recorded to produce pachybasin, chrysophanol, trichodermol, emodin, 1,3,6,8tetrahydroxyanthraquinone and 1-acetyl-2,4,5,7tetrahydroxyanthraquinone. Trichodermaol and Emodin possesses both monoamine oxidase inhibiting activity (Fujimoto et al., 1998) and tyrosine kinase (Jayasuriya et al., 1992; Kumar et al., 1998). T. viride, T. virens, T. harzianum and $T$. koningii are prolific producers of secondary metabolites such as trichodermin, viridol, peptaibols, pyrones, acarones, daucene, trichoderrmol, emodin, sterols, heterocyclic nitrogen compounds, sesquiterpenes, etc. (Weindling and Emerson, 1936; Sivasithamparam and Ghisalberti, 1998; Vyas and Mathur, 2002; Wiest et al., 2002; Mathivanan et al., 2008) ${ }^{[153,133,88]}$. Secretion of a variety of polysaccharide degrading enzymes including chitinases, glucanases, proteases and cellulases is a common feature of bacterial and fungal BCAs (Jan et al., 2011; Quecine et al., 2008) ${ }^{[61]}$. These enzymes are capable of degrading the cell walls of fungal (or oomycete) hyphae, chlamydospores, oospores, conidia, sporangia, and zoospores resulting in lysis and thus contribute to protection against Plant Disease.

\section{Microbial secondary metabolites in plant disease management}

Microbial metabolites of fungal, bacterial and actinomycetes antagonists have found capable of inhibiting the growth of various phytopathogens. Secondary metabolites produced by different microbes are as follows:

\section{Phenazine-1-carboxylic acid (PCA)}

It has been reported from $P$. fluorescens (Gurusiddaiah et al., 1986) ${ }^{[43]}$, P. chlororaphis (Pierson and Thomashow, 1992) ${ }^{[114]}$, P. aeruginosa (Anjaiah et al., 1998) ${ }^{[3]}$ and P. putida (Pathma et al., 2010) ${ }^{[110]}$. PCA has been reported to inhibit fungal pathogens such as Gaeumannomyces graminis var. tritici, Pythium sp., Rhizoctonia solani, Polyporus sp., Sarocladium oryzae, Macrophomina phaseolina, Pestalotia theae, various species of Colletotrichum etc. and bacterial pathogens, Actinomyces viscosus, Bacillus subtilis and Erwinia amylovora etc. (Gurusiddaiah et al., 1986; Sakthivel and Gnanamanickam, 1987; Thomashow et al., 1990; Ayyadurai et al., 2007; Pathma et al., 2010) ${ }^{[43,146,8,110]}$.

\section{Pyocyanin (PCN)}

Pyocyanin (1-hydroxy-5-methyl-phenazine) is predominantly produced by $P$. aeruginosa (Demange et al., 1987) ${ }^{[26]}$. This bluish coloured compound, is toxic to a wide range of fungi including Septoria tritici and bacteria (Hassan and Fridovich, 1980; Baron and Rowe, 1981; Flaishman et al., 1990) ${ }^{[49,11,}$ 138]. It is more stable than PCA and exhibits antifungal activities even in alkaline $\mathrm{pH}$ (Chin-A-Woeng et al., 1998)

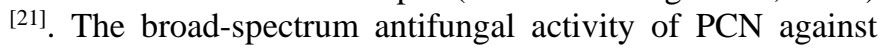
Pythium, Fusarium oxysporum f.sp. radiciopersici, S. oryzae and $R$. solani have been documented (Chin-AWoeng et al., 1998; Sunish Kumar et al., 2005) ${ }^{[21,137] .}$

\section{2, 4-diacetylphloroglucinol (DAPG)}

Production of 2,4-diacetylphloroglucinol (DAPG), a phenolic antibiotic, has been reported from $P$. fluorescens strains such as Pf-5, CHA0, Q2-87, F113, Q8r1-96. DAPG-producing strains are effective against Pythium, causal organism of damping-off in cotton (Howell and Stipanovic, 1980) ${ }^{[55]}$, soft rot of potato and take-all of wheat (Vincent et al., 1991; Fenton et al., 1992; Harrison et al., 1993; Pierson and Weller, 1994; Rosales et al., 1995; Raaijmakers and Weller, 1998) ${ }^{[150,}$

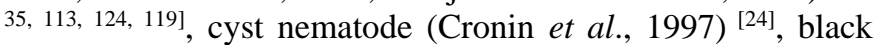
root rot of tobacco and root rot of tomato (Duffy and Defago, 1997) ${ }^{[29]}$.

\section{Pyoluteorin (PLT)}

$P$. fluorescens strain Pf-5 produces an antibiotic pyoluteorin (PLT), a bichlorinated antifungal metabolite of mixed polyketide/amino acid origin (Maurhofer et al., 1992; Maurhofer et al., 1994; Kraus and Loper, 1995; NowakThompson et al., 1997) ${ }^{[97,95,76]}$ and is found to be more effective against the oomycete, $P$. ultimum causing dampingoff disease (Maurhofer et al., 1992) ${ }^{[978]}$. Treatment of cotton seed with pyoluteorin or with $P$. fluorescens at the time of planting in $P$. ultimum-infested soil increased seedling survival from 33 to $65 \%$ and from 28 to $71 \%$, respectively (Howell and Stipanovic, 1982) ${ }^{[52]}$. The mode of action is by the selective inhibition of bacterial isoleucyl-tRNA synthetase (Bennett et al., 1999) ${ }^{[17]}$.

\section{Pyrrolnitrin (PRN)}

Pyrrolnitrin (PRN) has been reported from $P$. aureofaciens (Elander et al., 1968) ${ }^{[32]}$ and P. fluorescens (Kirner et al., 1998) ${ }^{[72]}$. PRN has been found to be active against a wide range of fungi belonging deuteromycota, ascomycota and basidiomycota. Hence, PRN is widely used as fungicide in agriculture. PRN producing Burkholderia cepacia showed a broad-spectrum antifungal activity towards phytopathogenic fungi including $R$. solani (Cartwright et al., 1995) ${ }^{[20]}$ and $P$. fluorescens BL915 has been reported as bacterial antagonists that suppress $R$. solani in cotton (Ligon et al., 2000) ${ }^{[81]}$.

\section{Hydrogen cyanide ( $\mathrm{HCN})$}

It is the most potent volatile compound produced by many soil bacteria. The HCN produced by antagonistic fluorescent pseudomonads (FPs) have been very well proved to have exemplary antifungal activity against phytopathogens. HCN in $P$. fluorescens $\mathrm{CHA} 0$ played an indispensible role in suppression of black root rot of tobacco caused by the fungus Thielaviopsis basicola (Voisard et al., 1981) ${ }^{[152]}$ and take-all disease of wheat caused by G. graminis var. tritici. Siddiqui et al., (2003) ${ }^{[130]}$ have clearly proved the protective nature of $\mathrm{HCN}$ produced by $P$. aeruginosa against Meloidogyne javanica, the root-knot nematode in tomato.

\section{Siderophores}

Siderophores, the iron-binding molecules produced by many rhizobacteria were responsible for inhibition of many phytopathogens. Examples of siderophores produced by BCAs are pyoverdin and pyochelin, which have been reported to contain antimicrobial activity on their own (Arora et al., 2001; Haas and Defago, 2005) ${ }^{[5,44]}$. However, in most of the studies, the siderophores have been reported to inhibit the pathogens by iron competition only. Siderophore-mediated 
biocontrol potential of Rhizobium meliloti against Macrophomina phaseolina, causal agent of charcoal rot of groundnut has been demonstrated (Arora et al., 2001) ${ }^{[5]}$. Mercado-Blanco et al., (2004) ${ }^{[98]}$ reported the siderophoremediated suppression of Verticilium wilt by root-associated Pseudomonas sp. Bano and Musarrat, (2004) ${ }^{[10]}$ have also demonstrated the role of siderophores produced by rhizobacteria for the control of Fusarium sp. Idris et al., (2007) ${ }^{[59]}$ have reported that several rhizobacteria showed inhibitory activity toward Pythium ultimum by the production of antibiotic metabolites and siderophores. In iron deficient medium, the siderophores have resulted in the increased inhibition of mycelia growth of the pathogen (Jayaprakashvel, 2008) ${ }^{[63]}$

\section{Zwittermicin A 14}

Zwittermicin A 14 produced by B. thuringiensis and B. cereus is a linear aminopolyol antibiotic (Silo-Suh et al., 1998) ${ }^{[132]}$. It has ability to suppress damping-off disease incited by Phytophthora medicaginis in alfalfa.

\section{Kurstakin}

Peptides of Kurstakin 18 exhibits antifungal activity against Stachybotrys charatum produced by Bacillus sp. (Hathout et al., 2000) ${ }^{[50]}$.

\section{Azole compound}

Recently, an azole compound produced by B. licheniformis MML2501 has been completely characterized for its disease control potential against $M$. phaseolina, the causative agent of dry root rot of groundnut. The purified azole compound has exceptional antifungal activity against many soil borne fungal phytopathogens except $R$. solani (Prashanth, 2007) ${ }^{[118]}$.

\section{Ammonia}

Howell and co-workers, (1988) ${ }^{[56]}$ have reported that volatile compounds such as ammonia produced by Enterobacter cloacae has successfully suppressed Pythium ultimuminduced damping-off of cotton. Kavitha et al., (2005) ${ }^{[66]}$ have isolated and purified a thermostable antifungal protein from Bacillus sp. which retained antifungal activity against $M$. grisea even after autoclaving, thus demonstrating thermostability of the compound. Blasticidin (Takeuchi et al., 1958) [141], kasugamycin (Umezawa et al., 1965) [149], polyoxins (Suzuki et al., 1965) ${ }^{[139]}$ and validamycins (Shibata et al., 1970) ${ }^{[129]}$ are few of the commercially successful metabolites of actinomycetes that are used in plant disease control.

An antifungal protein from the marine bacterium, Streptomyces sp. strain AP77 has been found to be inhibitory against Pythium porphyrae, a causative agent of red rot disease in Porphyra spp. (Woo et al., 2002) ${ }^{[156]}$. Secondary metabolites viz., 5, 7-dimethoxy-4-p methoxylphenylcoumarin and 5, 7-dimethoxy-4 phenylcoumarin produced by $S$. aureofaciens CMUAc 130 have effectively inhibited phytopathogenic fungi (Taechowisan et al., 2005b) ${ }^{[148]}$.

\section{Wuyiencin}

Wuyiencin produced by $S$. hygroscopicus var. wuyiensis inhibits the germination of Botrytis cinerea conidia (Zhong et al., 2004). Wuyiencin has shown broad spectrum activity against other bacterial and fungal phytopathogens and effectively controlled gray mold, leaf mold and powdery mildew diseases (Cui et al., 2010) ${ }^{[25]}$. Two antifungal aliphatic compounds, SPM5C-1 and SPM5C-2 with a lactone and ketone carbonyl unit, respectively, have been obtained from Streptomyces sp. PM5 and evaluated under in-vitro and in-vivo conditions against major rice pathogens, Pyricularia oryzae and $R$. solani (Prabavathy et al., 2006) ${ }^{[116]}$.

Several antimicrobial secondary metabolites of Streptomyces sp. MML1042 have been partially purified and demonstrated for the antifungal activity against many soil-borne fungal

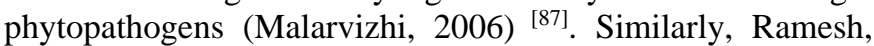
(2009) [121] has isolated and characterized bioactive compounds from Streptomyces MML1614 that has shown exceptional inhibitory activity against mycelial growth of $R$. solani and A. alternata. Metabolites such as 2,3-dihydroxy-5(hydroxymethyl) benzaldehyde, 4-(4 hydroxyphenoxy) butan2-one, acetic acid-2-hydroxy-6- (3-oxobutyl)-phenyl ester and 8-methyl decanoic acid effectively inhibited Fusarium wilt (Kavitha et al., 2010).

In-vivo antifungal activity of 5-hydroxyl-5-methyl-2-hexenoic acid from Actinoplanes sp. HBDN08 under greenhouse conditions has been demonstrated that metabolite could effectively control diseases caused by Botrytis cinerea, Cladosporium cucumerinum and Cladosporium cassiicola with $71.42,78.63$ and $65.13 \%$, respectively, at $350 \mathrm{mg} / \mathrm{L}$. This strong antifungal activity is suggestive of 5-hydroxyl-5methyl-2-hexenoic acid might be a promising candidate for new antifungal agents (Zhang et al., 2010).

\section{Viridin}

Viridin has been first described in 1945 as an antifungal metabolite of the fungus Gliocladium virens (Trichoderma virens) (Brian and McGowan, 1945). This compound has been detected in other Trichoderma species such as $T$. koningii (Beresteskii et al., 1976), T. viride (Golder and Watson, 1980) and T. virens (Singh et al., 2005) and prevents the germination of spores of Botrytis allii, Colletotrichum lini and Fusarium caeruleum (MIC of 0.003-0.006 lg/ml), Penicillium expansum, Aspergillus niger and Stachybotrys atra (6 lg/ml) (Brian and McGowan, 1945; Ghisalberti, 2002). The related C-3 alcohol viridiol has been obtained from $T$. viride and other Gliocladium species.

\section{Trichodermin}

Trichodermin has been first isolated in 1964 from a proposed T. viride strain (Godtfredsen and Vangedal, 1964). Subsequently, this compound has been obtained from $T$. polysporum and T. sporulosum (Adams and Hanson, 1972) and $T$. reesei (Watts et al., 1988).

\section{6-pentyl-2H-pyran-2-one}

The pyrone 6-pentyl-2H-pyran-2-one has been first identified by Collins and Halim, (1972) in culture broth of T. viride. Since then, it has been obtained from $T$. harzianum (Claydon et al., 1987) and T. koningii (Simon et al., 1988) and has been used in plate tests against Rhizoctonia solani and Fusarium oxysporum $\mathrm{f}$. sp. lycopersici with the addition of $0.3 \mathrm{mg} / \mathrm{ml}$ of 6-pentyl-2H-pyran-2-one to agar medium and resulted in $69.6 \%$ growth reduction in $R$. solani and a $31.7 \%$ reduction in $F$. oxysporum after 2 days. When used in spore germination tests at the rate of $0.45 \mathrm{mg} / \mathrm{ml}$ has been found to completely inhibit the germination of Fusarium spores. The control of Botrytis cinerea rots in stored kiwi fruits has also been investigated by Poole et al., (1998) with the application of pyrone 6-pentyl-2H-pyran-2-one at rates from 0.4 to $4 \mathrm{mg}$, neat or diluted in oil, water or acetone, consistently reduced 
the incidence of $B$. cinerea storage rots to low levels in both inoculated and naturally infected fruit.

\section{Gliovirin}

Gliovirin obtained from fungus Trichoderma has been found effective against Pythium ultimum (Howell and Stipanovic, 1983).

\section{Gliotoxin}

Strains producing gliotoxin has shown antagonistic activity against Rhizoctonia solani (Jones and Pettit, 1987)

\section{Harzianopyridone}

Racemic form of harzianopyridone has shown significant antifungal activity against Botrytis cinerea, Rhizoctonia solani (Dickinson et al., 1989) Gaeumannomyces graminis var. tritici and Pythium ultimum (Vinale et al., 2006).

\section{Harzianolide}

Harzianolide has been isolated from three different strains of T. harzianum (Almassi et al., 1991; Claydon et al., 1991; Ordentlich et al., 1992). In particular, harzianolide has been demonstrated to completely inhibit $G$. graminis var. tritici at the rate of $200 \mathrm{mg} / \mathrm{ml}$ and T39butenolide at $100 \mathrm{mg} / \mathrm{ml}$. Furthermore, they inhibited the growth of Rhizoctonia solani and Pythium ultimum (Vinale et al., 2006).

\section{Massoilactone and d-decanolactone}

The hydro-derivatives massoilactone and d-decanolactone have been patented by Hill et al., (1995) for their ability to control a range of plant afflictions including, for example, those produced by Botrytis or Phytophthora species.

In 1997, 5-hydroxyvertinolide a different butenolide of the vertinolide series has been isolated from the fungus $T$. longibrachiatum Rifai aggr. which is antagonistic to the fungus Mycena citricolor, the agent responsible for American leaf spot disease of coffee (Andrade et al., 1992).

\section{Viridepyronone}

Viridepyronone has been isolated from a cultural filtrate of a strain of $T$. viride. This compound has been shown antagonistic activity under in-vitro against Sclerotium rolfsii at a MIC of $196 \mathrm{mg} / \mathrm{ml}$ (>90\% inhibition) (Evidente et al., 2003).

\section{Koningins}

A series of complex pyranes named koninginins A-E and $G$ have been discovered in some species of Trichoderma. Koninginin D has also affected growth of other soil-borne plant pathogens such as Rhizoctonia solani, Phytophthora cinnamomi, Pythium middletonii, Fusarium oxysporum and Bipolaris sorokiniana.

\section{T22azaphilone}

Two commercial strains of $T$. harzianum have been found to produce T22azaphilone which has shown a marked in - vitro inhibition of Rhizoctonia solani, Pythium ultimum and Gaeumannomyces graminis var. tritici (Vinale et al., 2006).

\section{T39 butenolide}

T39 butenolide has been isolated from a commercially available $T$. harzianum strain (Vinale et al., 2006). This compound has shown antagonism towards the growth of the take-all fungus Gaeumannomyces graminis var. Tritici (Almassi et al., 1991; Vinale et al., 2006).

\section{Volatile compounds}

Isolates of Trichoderma viride and Trichoderma harzianum has shown inhibition on the growth of Fusarium moniliforme and Aspergillus flavus by producing inhibitory volatile compounds (Calistru et al., 1997). The volatile secondary metabolites produced by Trichoderma pseudokoningii, $T$. viride and Trichoderma aureoviride have affected the mycelia growth and protein synthesis in two isolates of Serpula lacrymans in varying degrees (Humphris et al., 2002).

\section{Nonanoic acid}

I. Garret and Robinson, (1969) have isolated nonanoic acid from Fusarium oxysporum, which inhibited the spore germination of Cunninghamella elegans.

\section{Trichothecin}

II. Trichothecin has been used in cotton seeds and crop plants to prevent wilt diseases (Askarova and Ioffe, 1962). Recently, Jayaprakashvel et al., (2010) ${ }^{[64]}$ have successfully controlled the sheath blight disease of rice under greenhouse conditions with thermostable, photostable crude metabolites of $T$. roseum MML003. The toxic metabolites produced by Fusarium chlamydosporum have effectively inhibited groundnut rust pathogen, Puccinia arachidis, and successfully reduce the number of pustules (Mathivanan, 1995) ${ }^{[90]}$. Further, an antifungal metabolite of p-disubstituted aromatic nature isolated from the culture filtrate of $F$. chlamydosporum inhibited the uredospore germination at $30 \mathrm{mg} / \mathrm{ml}$ concentration (Mathivanan and Murugesan, 1999) ${ }^{[91]}$.

\section{Fusapyrone and deoxyfusapyrone}

Two pyrones, viz., fusapyrone and deoxyfusapyrone from Fusarium semitectum have been highly active against Alternaria alternata, Ascochyta rabiei, Aspergillus flavus, Botrytis cinerea, Colletotrichum cucumerinum, Phoma tracheiphila and Penicillium verrucosum while they were least active against Fusarium spp. (Altomare et al., 2000) ${ }^{[1]}$.

\section{Lytic enzymes}

Many microorganisms produce and release lytic enzymes that can hydrolyze a wide variety of polymeric compounds, including chitin, proteins, cellulose, hemicellulose, and DNA. Expression and secretion of these enzymes by different microbes can sometimes result in the suppression of plant pathogen activities directly. For example, control of Sclerotium rolfsii by Serratia marcescens appeared to be mediated by chitinase expression (Ordentlich et al., 1988) [107]. And, a b-1,3-glucanase contributes significantly to biocontrol activities of Lysobacter enzymogenes strain C3 (Palumbo et al., 2005) ${ }^{[108] .}$ 
Table 1: Source of secondary metabolites and its target pathogens

\begin{tabular}{|c|c|c|c|c|}
\hline \multicolumn{2}{|c|}{\begin{tabular}{|l|l|} 
S. No. Secondary metabolite \\
\end{tabular}} & \multirow{2}{*}{$\begin{array}{c}\text { Source } \\
\text { Pseudomonas fluorescens } \\
\text { P.aureofaciens } P . \\
\text { aeruginosa }\end{array}$} & \multirow{2}{*}{$\begin{array}{c}\text { Target pathogen/disease } \\
\text { Gaeumannomyces gramini } \\
\text { var. tritici }\end{array}$} & \multirow{2}{*}{$\begin{array}{c}\text { References } \\
\text { Pierson and Pierson,1996; } \\
\text { Thomashow et al., } 1990^{[115,146]}\end{array}$} \\
\hline 1. & $\begin{array}{l}\text { Phenazine-1- } \\
\text { carboxylic } \\
\text { Acid (PCA) }\end{array}$ & & & \\
\hline 2. & $\begin{array}{l}\text { Phenazine-1- } \\
\text { carboxamide }\end{array}$ & $\begin{array}{l}\text { Pseudomonas aeruginosa } \\
\text { P. chlororaphis }\end{array}$ & $\begin{array}{c}\text { Fusarium oxysporum f.sp. radicislycopersici } \\
\text { Rhizoctonia solani }\end{array}$ & Shanmugaiah et al., 2010 \\
\hline 3. & Pyocyanin (PCN) & P. aeruginosa & Septoria tritici & $\begin{array}{c}\text { Baron and Rowe, 1981; Hassan } \\
\text { and Fridovich, 1980; Howell } \\
\text { and Stipanovic, 1980; Gutterson } \\
\quad \text { et al., } 1988^{[11,49,55]}\end{array}$ \\
\hline 4. & Anthranilate & P. aeruginosa & Fusarium oxysporum f.sp. ciceris, Pythium & Anjaiah et al., $1998^{[3]}$ \\
\hline 5. & Pyrrolnitrin (PRN) & P. fluorescens & Pythium ultimum & Howell and Stipanovic, $1980^{[55]}$ \\
\hline 6. & $\begin{array}{c}2,4- \\
\text { Diacetylphloroglucinol } \\
\text { (DAPG) }\end{array}$ & Pseudomonas fluorescens & $\begin{array}{l}\text { Gaeumannomyces gramini } \\
\text { var. tritici }\end{array}$ & $\begin{array}{c}\text { Nowak-Thompson et al., 1994; } \\
\text { Raaijmakers and Weller, } 1998^{[104,} \\
119]\end{array}$ \\
\hline 7. & $\begin{array}{l}\text { Hydrogen cyanide } \\
\text { (HCN) }\end{array}$ & $\begin{array}{l}P . \text { fluorescens } \\
P . \text { aeruginosa }\end{array}$ & $\begin{array}{c}\text { Thielaviopsis basicola } \\
\text { Gaeumannomyces gramini } \\
\text { var. tritici Rhizoctonia solani } \\
\text { Meloidogyne javanica }\end{array}$ & $\begin{array}{c}\text { Voisard } \text { et al., 1989, } \\
\text { Jayaprakashvel } \text { et al.., 2010, } \\
\text { Siddiqui } \text { et al., } 2003^{[152,64,130]}\end{array}$ \\
\hline 8. & Ammonia & $\begin{array}{l}\text { P. fluorescens } \\
\text { Enterobacter } \mathrm{sp} .\end{array}$ & Thielaviopsis basicola & $\begin{array}{l}\text { Howell et al., 1988, Candole and } \\
\text { Rothrock, 1997 [56] }\end{array}$ \\
\hline 9. & $\begin{array}{c}\text { Cyclic lipopeptides } \\
\text { like } \\
\text { viscosinamide tensin, } \\
\text { and amphisin } \\
\end{array}$ & $\begin{array}{l}\text { P. fluorescens } \\
\text { Burkholderia cepacia }\end{array}$ & Rhizoctonia solani & $\begin{array}{l}\text { Thrane } \text { et al., 2000, Nielsen et al., } \\
(1999,2002)^{[101,102]}\end{array}$ \\
\hline 10. & Gluconic acid & Pseudomonas strain AN5 & $\begin{array}{c}\text { Gaeumannomyces graminis } \\
\text { var. tritici } \\
\end{array}$ & Kaur et al., 2006 \\
\hline 11. & $\begin{array}{l}\text { Volatile organic } \\
\text { compound }\end{array}$ & $\begin{array}{c}\text { Pseudomonas spp., Serratia } \\
\text { spp., Stenotrophomonas } \\
\text { spp., etc } \\
\end{array}$ & $\begin{array}{l}\text { Many soil borne fungal } \\
\text { pathogens }\end{array}$ & $\begin{array}{l}\text { Dwivedi and Johri, 2003; Kai et al., } \\
\qquad 2007^{[31]}\end{array}$ \\
\hline 12. & Oomycin A & P.fluorescens & Pythium ultimum & Howie and Suslow, $1991^{[57]}$ \\
\hline 13. & Siderophore & $\begin{array}{l}\text { Pseudomonas sp. } \\
\text { Rhizobium meliloti }\end{array}$ & $\begin{array}{c}\text { Verticillium } \\
\text { Pythium } \\
\text { Fusarium } \\
\text { Macrophomina phaseolina }\end{array}$ & $\begin{array}{c}\text { Mercado-Blanco et al., 2004; Idris } \\
\text { et al., 2007; Bano and Musarrat, } \\
2004[98,59,10]\end{array}$ \\
\hline 14. & $\begin{array}{l}\text { Bacillomycin, } \\
\text { fengycin }\end{array}$ & \begin{tabular}{|c|} 
Bacillus amyloliquefaciens \\
FZB42
\end{tabular} & Fusarium oxysporum & Koumoutsi et al., $2004^{[75]}$ \\
\hline 15. & Bacillomycin D & Bacillus vallismortis ZZ185 & $\begin{array}{c}\text { Fusarium graminearum, } \\
\text { Alternaria alternata, } \\
\text { Rhizoctonia solani, } \\
\text { Cryphonectria parasitica } \\
\text { and Phytophthora capsici } \\
\text { Aspergillus flavus }\end{array}$ & $\begin{array}{l}\text { Zhao et al., } 2010 \\
\text { Moyne et al., } 2001\end{array}$ \\
\hline 16. & Iturin A & Bacillus subtilis & $\begin{array}{c}\text { Colletotrichum } \\
\text { gloeosporioides, } B . \text { cinerea } \\
\text { and } R \text {. solani }\end{array}$ & $\begin{array}{c}\text { Paulitz and } \\
\text { Belanger, 2001; } \\
\text { Kim et al., } 2010^{[111,70]}\end{array}$ \\
\hline 17. & Mycosubtilin & B. subtilis BBG100 & Pythium aphanidermatum & Leclere et al., $2005^{[78]}$ \\
\hline 18. & $\begin{array}{l}\text { Zwittermicin A } \\
\text { Kanasomine }\end{array}$ & Bacillus cereus UW85 & $\begin{array}{l}\text { Phytophthora medicaginis } \\
\text { and } P \text {. aphanidermatum }\end{array}$ & $\begin{array}{c}\text { Smith } \text { et al., 1993; } \\
\text { Milner } \text { et al., } 1996^{[134,100]}\end{array}$ \\
\hline 19. & Zwittermicin A 14 & $\begin{array}{l}\text { B. thurigiensis } \\
\text { B.cepacia }\end{array}$ & Phytophthora medicagnis & Silo-Suh et al., $1998^{[132]}$ \\
\hline 20. & Wuyiencin & $\begin{array}{l}\text { S. hygroscopius var. } \\
\text { wuyiensis }\end{array}$ & Botrytis cinerea & Zhong et al., 2004 \\
\hline 21. & Kurstakin 18 & B. thuringiensis & S. charatum & Hathout et al., $2000^{[50]}$ \\
\hline 22. & Xanthobaccin A & $\begin{array}{l}\text { Lysobacter sp. strain SB- } \\
\mathrm{K} 88\end{array}$ & Aphanomyces cochlioides & Islam et al., $2005^{[60]}$ \\
\hline 23. & Herbicolin & Pantoea agglomerans C9-1 & Erwinia amylovora & Sandra et al., 2001 [127] \\
\hline 24. & Pyrrolnitrin, pseudane & Burkholderia cepacia & R. solani and Pyricularia oryzae & Homma et al., $1989^{[52]}$ \\
\hline 25. & Agrocin 84 & Agrobacterium radiobacter & A. tumefaciens & Kerr, $1980^{[68]}$ \\
\hline 26. & Soraphen A & $\begin{array}{c}\text { Sorangium cellulosum (A } \\
\text { myxobacterium) }\end{array}$ & Erysiphe sp. & Gerth et al., 1994 \\
\hline 27. & $\begin{array}{c}\text { Pyrone 6-pentyl-2H- } \\
\text { pyran-2-one }\end{array}$ & $\begin{array}{l}\text { T. viride, } T \text {. harzianum, } T \text {. } \\
\text { koningii }\end{array}$ & $\begin{array}{l}\text { Rhizoctonia solani and Fusarium } \\
\text { oxysporum f. sp. lycopersici. }\end{array}$ & $\begin{array}{l}\text { Claydon et al., 1987; } \\
\text { Simon et al., } 1988\end{array}$ \\
\hline 28. & Viridepyronone & T. viride & Sclerotium rolfsii & Evidente et al., 2003 \\
\hline 29. & Koningin D & T. koningii & $\begin{array}{c}\text { Rhizoctonia solani, Phytophthora cinnamomi, } \\
\text { Pythium middletonii, Fusarium oxysporum and } \\
\text { Bipolaris sorokiniana }\end{array}$ & \\
\hline
\end{tabular}




\begin{tabular}{|c|c|c|c|c|}
\hline 30. & Viridin & \begin{tabular}{|c|} 
Glioclaudium \\
virens (Trichoderma virens) \\
T. koningii \\
\end{tabular} & $\begin{array}{c}\text { Botrytis allii, Colletotrichum lini, Fusarium } \\
\text { caeruleum, Penicillium expansum, Aspergillus } \\
\text { niger and Stachybotrys atra }\end{array}$ & $\begin{array}{l}\text { Brian and McGowan, 1945; } \\
\text { Ghisalberti, } 2002\end{array}$ \\
\hline 31. & Harzianopyridone & T. harzianum & $\begin{array}{c}\text { Botrytis cinerea, Rhizoctonia solani } \\
\text { Gaeumannomyces graminis var. Tritici and } \\
\text { Pythium ultimum }\end{array}$ & $\begin{array}{c}\text { Dickinson } \\
\text { et al., 1989; } \\
\text { Vinale } \text { et al., } 2006\end{array}$ \\
\hline 32. & T22azaphilone & T. harzianum & $\begin{array}{l}\text { Rhizoctonia solani, Pythium ultimum } \\
\text { and Gaeumannomyces graminis var. tritici }\end{array}$ & Vinale et al., 2006 \\
\hline 33. & 5-hydroxyvertinolide & T. longibrachiatum & Mycena citricolor & Andrade et al., 1992 \\
\hline 34. & Gliotoxin & T. viride, T. hamatum & Rhizoctonia solani & Jones and Pettit, 1987 \\
\hline 35. & Gliovirin & $\begin{array}{l}\text { Glioclaudium virens } \\
\text { (Trichoderma Virens) }\end{array}$ & Pythium ultimum & Howell and Stipanovic, 1983 \\
\hline 36. & Chitinase enzyme & Serratia marcescens & Sclerotium rolfsii & Ordentlich et al., $1988^{[107]}$ \\
\hline
\end{tabular}

\section{Conclusions}

It can be concluded that biological control of plant pathogens using the microbial metabolites produced by antagonistic microorganisms is an attractive substitute for chemically synthesized pesticides. Their specificity and non-persistence paved way for ecofriendly plant disease management and enables us to produce agricultural crops organically without posing threat to environment. Besides, use of these microbial metabolites as lead molecules for the synthesis of plant protective chemicals opens up new vistas for entrepreneurs and industrialists. Newer scientific approaches such as Microbial metabolic engineering in identifying novel agro active metabolites is yet to be followed vigorously. Sorbicillinoids, a hexaketide metabolite obtained from fungi can be tested against plant viruses for its antiviral activity. It can be the rich resources of biologically active substances with significant agricultural potential as well as ecofriendly without any detrimental effects on humans.

\section{References}

1. Altomare C, Perrone G, Zonno MC, Evidente A, Pingue $\mathrm{R}$, Fanti $\mathrm{F}$ et al. Biological characterization of fusapyrone and deoxyfusapyrone, two bioactive secondary metabolites of Fusarium semitectum. Journal of Natural Products. 2000; 63:1131-1135.

2. Amadioha AC. Control of Powdery mildew in pepper (Capsicum annum L.) by leaf extracts of papaya (Carica papaya L.). Journal of Herbs, Spices and Medicinal Plants. 1998; 6:41-47.

3. Anjaiah V, Koedam N, Nowak-Thompson B, Loper JE, Heofte M, Tambong JT et al. Involvement of phenazines and anthranilate in the antagonism of Pseudomonas aeruginosa PNA1 and Tn5-derivatives towards Fusarium sp. and Pythium sp. Molecular Plant Microbe Interactions. 1998; 11:847-54.

4. Arima K, Imanaka I, Kousaka M, Fukuta A, Tamura G. Pyrrolnitrin, a new antibiotic substance, produced by Pseudomonas. Agricultural and Biological Chemistry. 1964; 28:575-76.

5. Arora NK, Kang SC, Maheshwari DK. Isolation of siderophore-producing strains of Rhizobium meliloti and their biocontrol potential against Macrophomina phaseolina that causes charcoal rot of groundnut. Current Science. 2001; 81:673-77.

6. Askarova SA, Ioffe RI. On the possibility of the use of the fungicidal preparation trichothecin in the control of Fusarium decemcellulare on Puccinia psidii in guava (Psidium guajava). Antibiotics. 1962; 7:929-30.

7. Ayyadurai N, Ravindra Naik P, Sreehari Rao M, Sunish Kumar R, Samrat SK, Manohar M et al. Isolation and Characterization of a novel banana rhizosphere bacterium as fungal antagonist and microbial adjuvant in micropropagation of banana. Journal of Applied Microbiology. 100:926-37.

8. Ayyadurai N, Ravindra Naik P, Sakthivel N. Functional characterization of antagonistic fluorescent pseudomonads associated with rhizosphere soil of rice (Oryza sativa L.). Journal of Microbiology and Biotechnology. 2007; 17:919-27.

9. Balakrishnan K and Pandey A. Production of biologically active secondary metabolites in solid state fermentation. Journal of Scientific and Industrial Research. 1996; 55:365-372.

10. Bano N, Musarrat J. Characterization of a novel carbofuran degrading Pseudomonas sp. with collateral biocontrol and plant growth promoting potential. FEMS Microbiol Letters. 2004; 231:13-17.

11. Baron SS, Rowe JJ. Antibiotic action of pyocyanin. Antimicrobial Agents and Chemotherapy. 1981; 20:81420.

12. Barrios-Gonzalez J, Fernández FJ, Tomasini A, Mejía A. Production of secondary metabolites by solid state fermentation. Malaysian Journal of Microbiology. 2005; $1: 1-6$.

13. Barrios-Gonzalez J, Mejia A. Production of secondary metabolites by solid-state fermentation. Biotechnology Annual Review. 1996; 2:85-121.

14. Barrios-Gonzalez J, Tomasini A, Viniegra-Gonzalez G, Lopez L. Penicillin production by solid state fermentation. Biotechnology Letters. 1988; 10:793-798.

15. Bawden FC, Freeman GG. The nature and behavior of inhibitors of plant viruses produced by Trichothecium roseum Link. Journal of General Microbiology. 1952; 7:154-68.

16. Bennett RN, Wallsgrove RM. Secondary metabolites in plant defense mechanisms. New Phytologist. 1994; 127:617-33.

17. Bennett I, Broom NJP, Cassels R, Elder JS, Masson ND, O Hanlon PJ. Synthesis and antibacterial properties of $\hat{a}-$ diketone acrylate bioisosteres of pseudomonic acid A. Bioorganic and Medicinal Chemistry Letters. 1999; 9:1847-52.

18. Biju CN. Studies on Powdery Mildew of Pea (Pisum sativum L.) caused by Erysiphe polygoni DC. M.Sc.(Ag.) Thesis. University of Agricultural Sciences, Dharwad, India, 2000.

19. Busti E, Monciardini P, Cavaletti L, Bamonte R, Lazzarini A, Sosio. Microbiology. 2006; 152:675-83.

20. Cartwright DK, Chilton WS, Benson DM. Pyrrolnitrin and phenazine production by Pseudomonas cepacia, strain 5.5B, a biocontrol agent of Rhizoctonia solani. Applied Microbiology and Biotechnology. 1995; 43:21116. 
21. Chin-A-Woeng TFC, Bloomberg GV, Lugtenberg BJJ. Phenazines and their role in Biocontrol by Pseudomonas bacteria. New Phytopathology. 2003; 157:503-523.

22. Cook RJ, Baker KF. The nature and practice of biological control of plant pathogens. American Phytopathological Society, St. Paul, MN, 1983.

23. Cook RJ. Advances in plant health management in the 20th century. Annual Review of Phytopathology. 2000; 38:95-116.

24. Cronin D, Moenne-Loccoz Y, Fenton A, Dunne C, Dowling DN, O Gara F. Role of 2,4diacetylphloroglucinol in the interaction of the biocontrol pseudomonad strain F113 with the potato cyst nematode Globodera rostochiensis. Applied Environmental Microbiology. 1997; 63:1357-61.

25. Cui Z, Zhang K, She G, Lin Y, Sun L, Cheng Y et al. Antimicrobial activity investigation on wuyiencin fractions of different polarity. Molecules. 2010; 15:317985.

26. Demange $\mathrm{P}$, Wendenbaum S, Linget C, Bateman A, MacLeod J, Dell A et al. Bacterial siderophores: Structures and physicochemical properties of pyoverdines and related compounds. In: Winkelmann $\mathrm{G}$ and Weinheim VCH (Eds.), Iron Transport in Microbes, Plants and Animals. VCH Press, Weinheim, Germany, 1987, 189-205.

27. Doumbou CL, Hamby Salove MK, Crawford DL, Beaulieu C. Actinomycetes, promising tools to control plant diseases and to promote plant growth. Phytoprotection. 2002; 82:85-102.

28. Dowling DN, O'Gara F. Metabolites of Pseudomonas involved in the biocontrol of Plant Disease. Trends in Biotechnology. 1994; 12:133-41.

29. Duffy BK, Defago G. Zinc improves biocontrol of Fusarium crown and root rot of tomato by Pseudomonas fluorescens and represses the production of pathogen metabolites inhibitory to bacterial antibiotic biosynthesis. Phytopathology. 1997; 87:1250-57.

30. Dunne C, Cronin D, Moenne Loccoz Y, O Gura F, Duffy $\mathrm{B}$, Rosenberger $\mathrm{U}$ et al. Biological Control of Phytopathogens by Phluroglucinol and Hydrolytic Enzyme producing Bacterial Inoculants. Bulletin OILB SROP. 1998; 21:19-25.

31. Dwivedi D, Johri BN. Antifungals from fluorescent pseudomonads: biosynthesis and regulation. Current Science. 2003; 12:1693-1703.

32. Elander RP, Mabe JA, Hamill RH, Gorman M. Metabolism of tryptophans by Pseudomonas aureofaciens. VI. Production of pyrrolnitrin by selected Pseudomonas species. Applied Microbiology. 1968; 116:753-58.

33. El-Tarabily KA, Sivasithamparam K. Non-streptomycete actinomycetes as biocontrol agents of soil-borne fungal plant pathogens and as plant growth promoters. Soil Biology and Biochemistry. 2006; 38:1505-20.

34. Emmert EAB, Handelsman J. Biocontrol of plant disease: a (gram-) positive perspective. FEMS Microbiology Letters. 1999; 171:1-9.

35. Fenton AM, Stephens PM, Crowley J, O Callaghen M, O Gara F. Exploitation of genes involved in 2, 4diacetylphloroglucinol biosynthesis to confer a new biocontrol capability to a Pseudomonas strain. Applied Environmental Microbiology. 1992; 58:3873-78.
36. Firakova S, Sturdikova M, Muckova M. Bioactive secondary metabolites produced by microorganisms associated with plants. Biologia. 2007; 62:251-57.

37. Fisher PJ, Anson AE, Petrini O. Antibiotic activity of some endophytic fungi from ericaceous plants. Botanica Helvetica. 1984; 94:249-53.

38. Flaishman M, Eyal Z, Voisard C, Haas D. Suppression of Septoria tritici by phenazine or siderophore deficient mutants of Pseudomonas. Current Microbiology. 1990; 20:121-24.

39. Fravel D. Role of antibiosis in the biocontrol of plant diseases. Annual Review of Phytopathology. 1988; 26:75-91.

40. Fravel D. Commercialization and implementation of biocontrol. Annual Review of Phytopathology. 2005; 43:337-59.

41. Garret MK, Robinson PM. A stable inhibitor of spore germination produced by fungi. Archives in Microbiology. 1969; 67:370-377.

42. Gurney KA, Mantle PG. Biosynthesis of 1-Nmethylalbo- noursin by an endophytic Streptomyces sp. isolated from perennial ryegrass. Journal of Natural Products. 1993; 56:1194-98.

43. Gurusiddaiah S, Weller DM, Sarkar A, Cook RJ. Characterization of an antibiotic produced by a strain of Pseudomonas fluorescens inhibitory to Gaeumannomyces graminis var. tritici and Pythium spp. Antimicrobial Agents and Chemotherapy. 1986; 29:488-95.

44. Haas D, Defago G. Biological control of soil-borne pathogens by fluorescent pseudomonads. Natural Review of Microbiology. 2005; 3:307-19.

45. Hallmann J, Quadt-Hallmann A, Mahaffee WF, Kloepper JW. Bacterial endophytes in agricultural crops. Canadian Journal of Microbiology. 1997; 43:895-914.

46. Handelsman J, Stabb EV. Biocontrol of soil-borne plant pathogens. Plant Cell. 1996; 8:1855-69.

47. Harman GE, Howell CR, Vitarbo A, Chet I, Lorito M. Trichoderma species - opportunistic, avirulent plant symbionts. Natural Review of Microbiology. 2004; 2:4356.

48. Hassan AA, El-Barawy AM, Mokhtar El, Nahed M. Evaluation of biological compounds of Streptomyces species for control of some fungal diseases. Journal of American Science. 2011; 7:752-60.

49. Hassan HM, Fridovich I. Mechanism of the antibiotic action of pyocyanine. Journal of Bacteriology. 1980; 141:156-63.

50. Hathout Y, Ho YP, Ryzhov V, Demirev P, Fenselau C. Kurstakin: a new class of lipopeptides isolated from Bacillus thuringiensis. Journal of Natural Products. 2000; 63:1492-96.

51. Hoffman AM, Mayer SG, Strobel GA, Hess WM, Sovocool GW, Grange AH et al. Purification, identification and activity of phomodione, afuran- dione from an endophytic Phoma species. Phytochemistry. 2008; 69:1049-56.

52. Homma Y, Sato Z, Hirayama F, Konno K, Shirahama H, Suzui T. Production of antibiotics by Pseudomonas cepacia as an agent for biological control of soil borne pathogens. Soil Biology and Biochemistry. 1989; 21:72328.

53. Howell CR, Stipanovic RD. Mechanisms in the biocontrol of Rhizoctonia solani-induced cotton seedling disease by Gliocladium virens: antibiosis. Phytopathology. 1995; 85:469-72. 
54. Howell CR, Stipanovic RD, Lumsden RD. Antibiotic production by strains of Gliocladium virens and its relation to the biocontrol of cotton seedling diseases. Biocontrol Science and Technolology. 1993; 3:435-441.

55. Howell CR, Stipanovic RD. Suppression of Pythium ultimum-induced damping-off of cotton seedlings by Pseudomonas fluorescens and its antibiotic, pyoluteorin. Phytopathology. 1980; 70:712-15.

56. Howell CR, Beier RC, Stipanovic RD. Production of ammonia by Enterobacter cloacae and its possible role in the biological control of Pythium pre-emergence damping-off by the bacterium. Phytopathology. 1988; 78:1075-78.

57. Howie WJ, Suslow TV. Role of antibiotic biosynthesis in the inhibition of Pythium ultimum in the cotton spermosphere and rhizosphere by Pseudomonas fluorescens. Molecular Plant Microbe Interactions. 1991; 4:393-99.

58. Humphris SN, Bruce A, Buultjens E, Wheatley RE. The effects of volatile microbial secondary metabolites on protein synthesis in Serpula lacrymans. FEMS Microbiology Letters. 2002; 210:215-19.

59. Idris AH, Labuschagne $\mathrm{N}$, Korsten L. Screening rhizobacteria for biological control of Fusarium root and crown rot of sorghum in Ethiopia. Biological Control. 2007; 40:97-106.

60. Islam Md T, Hashidoko Y, Deora A, Ito T, Tahara S. Suppression of damping-off disease in host plants by the rhizoplane bacterium Lysobacter sp. strain SB-K88 is linked to plant colonization and antibiosis against soilborne peronosporomycetes. Applied Environmental Microbiology. 2005; 71:3786-96.

61. Jan AT, Azam M, Ali A, Haq QMR. Novel approaches of beneficial Pseudomonas in mitigation of plant diseases an appraisal. Journal of Plant Interaction. 2011; 6:195205.

62. Jayaprakashvel M, Mathivanan N. Biological control and its implications on rice diseases management. In: Ponmurugan P, Deepa MA (eds) Role of biocontrol agents for disease management in sustainable agriculture. Scitech, Chennai, India. 2009, 440-455.

63. Jayaprakashvel M. Development of a synergistically performing bacterial consortium for sheath blight suppression in rice. Ph.D. thesis, University of Madras, Madras, India, 2008.

64. Jayaprakashvel M, Muthezhilan R, Srinivasan R, Jaffar Hussain A, Gopalakrishnan S, Bhagat J et al. Hydrogen cyanide mediated biocontrol potential of Pseudomonas sp. AMET1055 isolated from the rhizosphere of coastal sand dune vegetation. Advanced Biotech. 2010; 9:39-42.

65. Jayaprakashvel M, Ramesh S, Mathivanan N, Baby UI. Prevalence of fluorescent pseudomonads in the rhizosphere of plantation crops and their antagonistic properties against certain phytopathogens. Journal of Plantation Crops. 2006; 34:728-32.

66. Kavitha S, Senthilkumar S, Gnanamanickam SS, Inayathullah M, Jayakumar J. Isolation and partial characterization of antifungal protein from Bacillus polymyxa strain VLB16. Process in Biochemistry. 2005; 40:3236-43.

67. Keel C, Schnider U, Maurhofer M, Voisard C, Laville J, Burger $\mathrm{P}$ et al. Suppression of root diseases by Pseudomonas fluorescens CHA0: importance of the bacterial secondary metabolite, 2, 4- diacetylphloroglucinol. Molecular Plant Microbe Interactions. 1992; 5:4-13.

68. Kerr A. Biological control of crown gall through production of agrocin 84. Plant Disease. 1980; 64:25-30.

69. Khalil R, Djadouni F, Elbahloul Y, Omar S. The influence of cultural and physical conditions on the antimicrobial activity of bacteriocin produced by a newly isolated Bacillus megaterium 22 strains. African Journal of Food Science. 2009; 3:11-22.

70. Kim PI, Ryu J, Kim YH, Chi YT. Production of biosurfactant lipopeptides Iturin A, fengycin and surfactin A from Bacillus subtilis CMB32 for control of Colletotrichum gloeosporioides. Journal of Microbiology and Biotechnology. 2010; 20:138-45.

71. Kim BS, Hwang BK. Microbial fungicides in the control of plant diseases. Journal of Phytopathology. 2007; 155:641-53.

72. Kirner S, Hammer PE, Hill DS, Altmann A, Fischer I, Weislo LJ et al. Functions encoded by pyrrolnitrin biosynthetic genes from Pseudomonas fluorescens. Journal of Bacteriology. 1998; 180:1939-43.

73. Kloepper JW, Ryu CM, Zhang S. Induced systemic resistance and promotion of plant growth by Bacillus spp. Phytopathology. 2004; 94:1259-66.

74. Kobayashi DY, Palumbo JD. Bacterial endophytes and their effects on plants and uses in agriculture. In: Bacon CW, White JF, editors. Microbial endophytes. NY: Marcel Dekker, 2000, 199-233.

75. Koumoutsi A, Chen XH, Henne A, Liesegang $H$, Gabriele H, Franke $\mathrm{P}$ et al. Structural and functional characterization of gene clusters directing non ribosomal synthesis of bioactive lipopeptides in Bacillus amyloliquefaciens strain FZB42. Journal of Bacteriology. 2004; 186:1084-96.

76. Kraus J, Loper JE. Characterization of a genomic region required for production of the antibiotic pyoluteorin by the biological control agent Pseudomonas fluorescens Pf5. Applied Environmental Microbiology. 1995; 61:84954.

77. Kusari S, Verma VC, Lamshoeft M, Spiteller M. An endophytic fungus from Azadirachta indica A. Juss. that produces azadirachtin. World Journal of Microbiology and Biotechnology. 2012; 28:1287-1294.

78. Leclere VM, Bechet A, Adam JS, Guez B, Wathelet M, Ongena $\mathrm{P}$ et al. Mycosubtilin overproduction by Bacillus subtilis BBG100 enhances the organism's antagonistic and biocontrol activities. Applied Environmental Microbiology. 2005; 71:4577-84.

79. Li J, Zhao GZ, Chen HH, Wang HB, Qin S. Anti-tumour and antimicrobial activities of endophytic streptomycetes from pharmaceutical plants in rainforest. Letters in Applied Microbiology. 2008; 47:574-580.

80. Liarzi O, Bucki P, Braun Miyara S, Ezra D. Bioactive volatiles from an endophytic Daldinia $c f$. concentrica isolate affect the viability of the plant parasitic nematode Meloidogyne javanica. 2016.

81. Ligon JM, Hill DS, Hammer PE, Torkewitz NR, Hofmann D, Kempf HJ et al. Natural products with antifungal activity from Pseudomonas biocontrol bacteria. Pest Management Science. 2000; 56:688-95.

82. Liu CM, Westley JW, Herman TE, Prasser BLT, Palleroni N, Evans RH et al. Journal of Antibiotics. 1986; 39:1712-18. 
83. Liu X, Li S. Fungal secondary metabolites in biological control of crop pests. In: An Z (ed) Handbook of industrial mycology. CRC, New York, 2004, 723-747

84. Lonsane BK, Ghildyal NP, Sreenivasamurthy V. Engineering aspects of solid-state fermentation. Enzyme and Microbial Technology. 1985; 7:258-265.

85. Lu H, Zou WX, Meng JC, Hu J, Tan RX. New bioactive metabolites produced by Colletotrichum sp., an endophytic fungus in Artemisia annua. Plant Science. 2000; 151:67-73.

86. Macı'as-Rubalcava ML, Herna'ndez-Bautista BE, Jime'nez-Estrada M, Gonza'lez MC, Glenn AE, Hanlin RT. Naphthoquinone spiroketal with allele chemical activity from the newly discovered endophytic fungus Edenia gomezpompae. Phytochemistry. 2008; 69:118596.

87. Malarvizhi K. Biodiversity and antimicrobial potential of soil actinomycetes from south India: isolation, purification and characterization of an antifungal metabolite produced by Streptomyces sp. MML1042. Ph.D. thesis, University of Madras, Madras, India, 2006.

88. Mathivanan N, Prabavathy VR, Vijayanandraj VR. The effect of fungal secondary metabolites on bacterial and fungal pathogens. In: Karlovsky $\mathrm{P}$ (ed) Secondary metabolites in soil ecology. Springer, Berlin, 2008, 129140.

89. Mathivanan N, Srinivasan K, Chelliah S. Evaluation of Trichoderma viride and Carbendazim and their integration for the management of root diseases in cotton. Indian Journal of Microbiology. 1997; 37:107-108.

90. Mathivanan N. Studies on extracellular chitinase and secondary metabolites produced by Fusarium chlamydosporum, an antagonist to Puccinia arachidis, the rust pathogen of groundnut. Ph.D. thesis, University of Madras, Madras, India, 1995.

91. Mathivanan N, Murugesan K. Isolation and purification of an antifungal metabolite from Fusarium chlamydosporum, a mycoparasite to Puccinia arachidis, the rust pathogen of groundnut. Indian Journal of Experimental Biology. 1999; 37:98-101.

92. Mathivanan N, Manibhushanrao K. An overview of current strategies on biological control of soil-borne pathogens. In: Prakash HS, Niranjana RS (eds) Vistas in applied botany. Department of Applied Botany and Biotechnology, University of Mysore, Mysore, India, 2004, 119-148

93. Mathivanan N, Manibhushanrao K, Murugesan K. Biological control of plant pathogens. In: Anand N (ed) Recent trends in botanical research. University of Madras, Chennai, India, 2006, 275-323.

94. Mathre DE, Cook RJ, Callan NW. From discovery to use: traversing the world of commercializing biocontrol agents for plant disease control. Plant Disease. 1999; 83:972-983.

95. Maurhofer M, Keel C, Haas D, Defago G. Pyoluteorin production by Pseudomonas fluorescens strain CHA0 is involved in the suppression of Pythium damping off of cress but not cucumber. European Journal of Plant Pathology. 1994; 100:221-232.

96. Maurhofer M, Hase C, Meuwly P, Metraux JP, Defago $\mathrm{G}$. Induction of systemic resistance of tobacco mosaic virus by the root colonizing Pseudomonas fluorescens strain CHA0: influence of the gacA gene of pyoverdine production. Phytopathology. 1994; 84:139-146.
97. Maurhofer M, Keel C, Schnider U, Viosard C, Haas D, Defago G. Influence of enhanced antibiotic production in Pseudomonas fluorescens strain CHA0 on its disease suppressive capacity. Phytopathology. 1992; 82:190-195.

98. Mercado-Blanco J, Rodrguez Jurado D, Hervas A, Jimenez Daza RM. Suppression of Verticillium wilt in olive planting stocks by root associated fluorescent Pseudomonas spp. Biological Control. 2004; 30:474-86.

99. Miller MB, Bassler BL. Quorum sensing in bacteria. Annual Review of Microbiology. 2001; 55:165-99.

100. Milner JL, Silo-Suh LA, Lee JC, He H, Clardy J, Handelsman J. Production of kanosamine by Bacillus cereus UW85. Applied Environmental Microbiology. 1996; 62:3061-65.

101.Nielsen MN, Sorensen J. Chitinolytic activity of Pseudomonas fluorescens isolates from barely and sugar beet rhizosphere. FEMS Microbiology Ecology. 1999; 30:217-27.

102. Nielsen TH, Sorensen D, Tobiasen T, Andersen JB, Christophersen C, Givskov $\mathrm{M}$ et al. Antibiotic and biosurfactant properties of cyclic lipopeptides produced by fluorescent Pseudomonas spp. from the sugar beet rhizosphere. Applied and Environmental Microbiology. 2002; 68:3416-23.

103. Nielsen TH, Christophersen C, Anthoni U, Sorensen J. Viscosinamide, a new cyclic depsipeptide with surfactant and antifungal properties produced by Pseudomonas fluorescens. Jounal of Applied Microbiology. 1999; 86:80-90.

104.Nowak-Thompson B, Gould SJ, Kraus J, Loper JE. Production of 2, 4-diacetylphloroglucinol by the biocontrol agent Pseudomonas fluorescens Pf-5. Canadian Journal of Microbiology. 1994; 40:1064-1066.

105. Ohno A, Takashi A, Shoda M. Production of the antifungal peptide antibiotic, iturin, by Bacillus subtilis $\mathrm{N}$ B22. Biotechnology Letters. 1993; 14:1165-1168.

106. Omura S, Tanaka Y, Takahashi Y, Chia I, Inoue M, Iwai Y. Irumamycin, an antifungal 20- membered macrolide produced by a Streptomyces. Taxonomy, fermentation and biological properties. Journal of Antibiotics (Tokyo). 1984; 37:1572-1578.

107. Ordentlich A, Elad Y, Chet I. The role of chitinase of Serratia marcescens in the biocontrol of Sclerotium rolfsii. Phytopathology. 1988; 78:84-88.

108. Palumbo JD, Yuen GY, Jochum CC, Tatum K, Kobayashi DY. Mutagenesis of beta-1, 3-glucanase genes in Lysobacter enzymogenes strain C3 results in reduced biological control activity toward Bipolaris leaf spot of tall fescue and Pythium damping-off of sugar beet. Phytopathology. 2005; 95:701-707.

109.Parekh J, Chanda SV. Turk. Jounal of Biology. 2007; 31:53-58.

110.Pathma J, Ayyadurai N, Sakthivel N. Assessment of genetic and functional relationship of antagonistic fluorescent pseudomonads of rice rhizosphere by repetitive sequence, protein coding sequence and functional gene analyses. Journal of Microbiology. 2010; 48:715-727.

111.Paulitz TC, Belanger RR. Biological control in greenhouse systems. Annual Review of Phytopathology. 2001; 39:103-33.

112.Pfender WF, Kraus J, Loper JE. A genomic region from Pseudomonas fluorescens Pf-5 required for pyrrolnitrin production and inhibition of Pyrenophora tritici-repentis in wheat straw. Phytopathology. 1993; 83:1223-28. 
113.Pierson EA, Weller DM. Use of mixtures of fluorescent pseudomonads to suppress take-all and improve the growth of wheat. Phytopathology. 1994; 84:940-947.

114.Pierson LS, Thomashow LS. Cloning of heterologous expression of phenazine biosynthesis locus from Pseudomonas aureofaciens 30-84. Molecular PlantMicrobe Interactions. 1992; 53:330-339.

115.Pierson LS III, Pierson EA. Phenazine antibiotic production in Pseudomonas aureofaciens: role in rhizosphere ecology and pathogen suppression. FEMS Microbiology Letters. 1996; 136:101-108.

116. Prabavathy VR, Mathivanan N, Murugesan K. Control of blast and sheath blight diseases of rice using antifungal metabolites produced by Streptomyces sp. PM5. Biological Control. 2006; 39:313-319.

117.Prabavathy VR, Vajayanandraj VR, Malarvizhi K, Mathivanan N, Mohan N, Murugesan K. Role of actinomycetes and their metabolites in crop protection. In: Khachatourian GC, Arora DK, Rajendran TP, Srivastava AK (eds) Agriculturally important microorganisms. Academic World International, Bhopal, India, 2008, 243-255.

118. Prashanth S. Biological control of Macrophomina root rot and plant growth promotion in groundnut by Bacillus licheniformis MML2501, an azole compound producing rhizobacterium. Ph.D. thesis, University of Madras, Madras, India, 2007.

119. Raaijmakers JM, Weller DM. Natural plant protection by 2, 4-diacetylphloroglucinol producing Pseudomonas spp. in take-all decline soils. Molecular Plant Microbe Interactions. 1998-2007; 11:144-152.

120.Ramamoorthy V, Viswanathan R, Raguchander T, Prakasam V, Samiyappan R. Induction of systemic resistance by plant growth promoting rhizobacteria in crop plants against pests and diseases. Crop Protection. 2001; 20:1-11.

121. Ramesh S. Marine actinomycetes diversity in Bay of Bengal, India: isolation and characterization of bioactive compounds from Streptomyces fungicidicus MML1614. Ph.D. thesis, University of Madras, Madras, India, 2009.

122. Ravikumar BP. Studies on Powdery Mildew of Rose (Rosa spp.) caused by Sphaerotheca pannosa var. rosae (Wallr). M.Sc. Thesis. University of Agricultural Sciences, Dharwad, India, 1998.

123. Robinson T, Singh D, Nigam P. Solid-state fermentation: a promising microbial technology for secondary metabolite production. Applied Microbiology and Bitechnology. 2001; 55:284-289.

124. Rosales AM, Thomashow LS, Cook RJ, Mew TW. Isolation and identification of antifungal metabolite produced by rice associated antagonistic Pseudomonas spp. Phytopathology. 1995; 85:1028-32.

125.Rosenblitt A, Agosin E, Perez-Correa JR, Delgado J. Solid substrate fermentation of Monascus purpureus; Growth, carbon balance and consistency analysis. Biotechnology Progress. 2000; 16:152-162.

126. Sakthivel N, Gnanamanickam SS. Evaluation of Pseudomonas fluorescens for suppression of sheath-rot disease and for enhancement of grain yields in rice (Oryza sativa L). Applied and Environmental Microbiology. 1987; 53:2056-2059.

127. Sandra AI, Wright CH, Zumoff LS, Steven VB. Pantoea agglomerans strain EH318 produces two antibiotics that inhibit Erwinia amylovora in-vitro. Applied and Environmental Microbiology. 2001; 67:282-292.
128. Sansinenea E, Ortiz A. Secondary metabolites of soil Bacillus spp. Biotechnology Letters. 2011; 33:1523-38.

129. Shibata M, Iwasa T, Wakae O, Matsuura K, Yamamoto H, Asai M et al. DE Patent 1954110, Takeda Chemical Industries, Ltd., 1970.

130. Siddiqui IA, Shaukat SS, Khan GH, Ali NA. Suppression of Meloidogyne javanica by Pseudomonas aeruginosa IE-6S+ in tomato: the influence of $\mathrm{NaCl}$, oxygen and iron levels. Soil Biology and Biochemistry. 2003; 35:1625-34.

131. Siddiqui ZA. PGPR: Prospective biocontrol agents of plant pathogens. In: Siddiqui, Z. A. (Ed.), PGPR: Biocontrol and Biofertilization, Springer, The Netherlands, 2006, 111-142.

132. Silo-Suh LA, Stabb EV, Raffel SJ, Handelsman J. Target range of zwittermicin $\mathrm{A}$, an aminopolyol antibiotic from Bacillus cereus. Current Microbiology. 1998; 37:6-11.

133. Sivasithamparam K, Ghisalberti EL. Secondary metabolism in Trichoderma and Gliocladium. In: Kubicek CP, Harman GE (eds) Trichoderma and Gliocladium, Taylor and Francis, London, 1998; 1:139191.

134. Smith KP, Havey MJ, Handelsman J. Suppression of cottony leak of cucumber with Bacillus cereus strain UW85. Plant Disease. 1993; 77:139-42.

135. Sorensen D, Nielsen TH, Christophersen C, Sorensen J, Gajhede M. Cyclic lipoundecapeptide Amphisin from Pseudomonas sp. strain DSS73. Acta Crystallographica Section C-Crystal Structure Communications. 2001; 57:1123-1124.

136. Strobel GA, Torzynski R, Bollon A. Acremonium sp.-a leucinostatin producing endophyte of European yew (Taxus baccata ). Plant Science. 1997; 128:97-108.

137. Sunish Kumar R, Ayyadurai N, Pandiaraja P, Reddy AV, Venkateswarlu Y, Prakash $\mathrm{O}$ et al. Characterization of antifungal metabolite produced by a new strain Pseudomonas aeruginosa PUPa3 that exhibits broadspectrum antifungal activity and biofertilizing traits. Journal of Applied Microbiology. 2005; 98:145-154.

138. Suzni T. Biological control of soil borne diseases with antagonistic microbes. In: Kim SU (ed) New biopesticides: proceedings of the agricultural biotechnology symposium. The Research Center of New Bio-Materials in Agriculture, Suweon, Korea, 1992, 5576

139. Suzuki S, Isono K, Nagatsu J, Mizutani T, Kawashima Y, Mizuno T. A new antibiotic, polyoxin A. Journal of Antibiotics. 1965; 18:131.

140. Taechowisan T, Lu C, Shen Y, Lumyong S. 4Acrylcoumarins from endophytic Streptomyces aureofaciens CMUAc 130 and their antifungal activity. Annals of Microbiology. 2005; 55:63-66.

141. Takeuchi S, Hirayama K, Ueda K, Sakai H, Yonehara H. Blasticidin S, a new antibiotic. Journal of Antibiotics. 1958; 11:1-5.

142. Tanaka Y, Omura S. Agroactive compounds of microbial origin. Annual Review of Microbiology. 1993; 47:57-87.

143. Thangadurai S, Shukla SK, Anjaneyulu Y. 2002. Analytical Science. 1993; 18:97-100.

144. Thirumurugan D, Cholarajan A, Raja SS, Vijayakumar R. An Introductory Chapter: Secondary Metabolites, 2018.

145. Thomashow LS, Weller DM. Role of a phenazine antibiotic from Pseudomonas fluorescens in biological control of Gaeumannomyces graminis var. tritici. Journal of Bacteriology. 1988; 170:3499-3508. 
146. Thomashow LS, Weller DM, Bonsall RF, Pierson LS. Production of the antibiotic phenazine 1-carboxylic acid by fluorescent Pseudomonas species in the rhizosphere of wheat. Applied and Environmental Microbiology. 1990; 56:908-912.

147. Tomasini A, Fajardo CL, Gonzalez JB. Gibberellic acid production using different solid state fermentation systems. World Journal of Microbiology and Biotechnology. 1997; 13:203-206.

148. Tuntiwachwuttikul $\mathrm{P}$, Taechowisan $\mathrm{T}$, Wanbanjob $\mathrm{A}$, Thadaniti S, Taylor WC. Lansai A.-D. secondary metabolites from Streptomyces sp. SUC1.Tetrahedron. 2008; 64:7583-6.

149. Umezawa H, Okami Y, Hashimoto T, Sukara Y, Hamada M, Takeuchi M. A new antibiotic, kasugamycin. Journal of Antibiotics. 1965; 18:101-103.

150. Vincent MN, Harrison LA, Brackin JM, Kovacevich PA, Mukerji P, Weller DM et al. Genetic analysis of the antifungal activity of a soil borne Pseudomonas aureofaciens strain. Applied and Environmental Microbiology. 1991; 57:2928-2934.

151.Vining LC. Functions of secondary metabolites. Annual Review of Microbiology. 1990; 44:395-427.

152. Voisard C, Keel C, Haas D, Defago G. Cyanide production by Pseudomonas fluorescens helps suppress black root of tobacco under gnotobiotic conditions. EMBO Journal. 1989; 8:351-58.

153. Weindling $\mathrm{R}$, Emerson $\mathrm{OH}$. The isolation of a toxic substance from the culture of a Trichoderma. Phytopathology. 1936; 26:1068-70.

154.Weller DM, Raaijmakers J, McSpadden Gardener B, Thomashow LM. Microbial populations responsible for specific soil suppressiveness to plant pathogens. Annual Review of Phytopathology. 2002; 40:309-348.

155. Wiest A, Grzegorski D, Xu BW, Goulard C, Rebuffat S, Ebbole DJ et al. Identification of peptaibols from Trichoderma virens and cloning of a peptaibol synthetase. Journal of Biology and Chemistry. 2002; 277:20862-68.

156. Woo JH, Kitamura E, Myouga H, Kamei Y. An antifungal protein from the marine bacterium Streptomyces sp. strain AP77 is specific for Pythium porphyrae, a causative agent of red rot disease in Porphyra spp. Applied and Environmental Microbiology. 2002; 68:2666-75.

157. Yamaguchi I. Pesticides of microbial origin and applications of molecular biology. In: Copping LG (ed) Crop protection agents from nature: natural products and analogues. The Royal Society of Chemistry, Cambridge, 1996, 27-49.

158. Yu GY, Sinclair JB, Hartman GL, Bertagnolli BL. Production of iturin A by Bacillus amyloliquefaciens suppressing Rhizoctonia solani. Soil Biology and Biochemistry. 2002; 34:955-963.

159.Zhang J, Banko G, Wolfe S, Demain AL. Methionine induction of ACV synthetase in Cephalosporium acremonium. Journal of Indian Microbiology. 1987; 2:251-255.

160.Zhao Z, Wang Q, Wang K, Brian K, Liu C, Gu Y. Study of the antifungal activity of Bacillus vallismortis ZZ185 in-vitro and identification of its antifungal components. Bioresource Technology. 2010; 101:292-297.

161.Zinniel DK, Lambrecht P, Harris NB, Feng Z, Kuczmarski D, Higley P. Isolation and characterization of endophytic colonizing bacteria from agronomic crops and prairie plants. Applied and Environmental Microbiology. 2002; 68:2198-2208. 